\title{
Noves consideracions al voltant de Bernat Fenollar, domer de la Seu de València
}

\section{New contributions regarding Bernat Fenollar, domerius of Valencia Cathedral}

\author{
FREDERIC APARISI \\ frederic.aparisi@uv.es \\ Universitat de València
}

\begin{abstract}
Resum: Bernat Fenollar ha atret l'atenció dels historiadors de la llengua per la seua implicació en el desenvolupament literari de la València de la segona meitat del Quatre-cents i per la producció literària pròpia. Més rar ha estat linnterés dels historiadors socioeconòmics i de l'església. Aquest treball incideix precisament en aquestes dues perspectives, la socioeconòmica i l'eclesiàstica per fer un recorregut per la trajectòria vital i professional del domer de la Seu. Per tant, queden al marge les qüestions referides a l'àmbit literari. Per a la confecció del present treball s'ha fet servir els registres eclesiàstics procedents de l'Arxiu de la Seu de València però sobretot protocols notarials procedents de quatre fons, això és, l'esmentada Seu, l'Arxiu del Regne de València, l'Arxiu de protocols notarials del col legi del Corpus Christi de València i l'Arxiu parroquial de Penàguila. Això ha permès perfilar la seua parentela i les seues relacions familiars, les seues fonts d'ingressos, que anaven més enllà de la seua retribució com a beneficiat i dels seus treballs en l'administració de la catedral, i plantejar una possible data per a la seua mort.
\end{abstract}

Paraules clau: Bernat Fenollar, Elits rurals, Poesia catalana, Seu de València

\begin{abstract}
Bernat Fenollar has attracted the attention of literature historians for his involvement in the literary development of Valencia in the second half of the fourteenth century and for his own literary works. The interest of socioeconomic and ecclesiastical historians has been more unusual. This work focuses indeed on these two perspectives, the socio-economic and the ecclesiastical, to revise the personal and professional trajectory of the domer de la Seu. Therefore, issues related to the literary field are left out. For the achieving all this, the ecclesiastical records from the Arxiu de la Catedral de València have been used, but above all notarial records from four archieves, that is, the said Cathedral, the Arxiu del Regne de València, the Arxiu de Protocols del Col legi Corpus Christi College de València and Arxiu Parroquial de Penàguila. This has made it possible to outline his kinship and his family relationships, his sources of income, which went beyond his remuneration as a clergyman and his work in the administration of the cathedral, and to suggest a possible date for his death.
\end{abstract}

Keywords: Bernat Fenollar, Rural Elites, Catalan Poetry, Cathedral of Valencia

\footnotetext{
* El present article s'insereix en el marc del treball desenvolupat en el projecte «¿Crecimiento sin desarrollo? Distribución de la riqueza, movilidad social y acción política en la Europa mediterránea (siglos XIII-XV)», dirigit per Antoni Furió, ref. PGC18099275B100 B-11/09 (MCI/AEI/FEDER, UE).
}

DATA PRESENTACIÓ: 01/04/2021 ACCEPTACIÓ: 14/04/2021 ·PUBLICACIÓ: 01/06/2021 


\section{Orígens familiars}

Bernat Fenollar nasqué a Penàguila, al si d'una família benestant vinculada a l'administració i a la notaria, atès que el seu pare era el batle de la vila, el notari Joan Fenollar (Germà \& Ferrando 2011: 171). De fet, encara a les darreries de la centúria el seu germà Mateu reconeixia ser natural de la vila. ${ }^{1}$ Amb tot, els primers anys del futur domer de la Seu són força difusos no sols per la falta de documentació sinó també per l'homonímia dels membres de la nissaga, cosa que ha dificultat la seua identificació i ha produït més d'una confusió. Ara per ara, la referència més antiga dels Fenollar a Penàguila data de setembre de 1412 quan el Consell de la ciutat de València -com a senyor titular de la vila- ${ }^{2}$ envià una lletra missiva al justícia, anomenat Joan Fenollar. ${ }^{3}$ Dos anys més tard, el Consell de la capital nomenava batle un altre membre del llinatge, Mateu Fenollar. ${ }^{4}$ Posteriorment, a la nòmina per a la recaptació de l'impost del morabatí de 1421, els Fenollar hi apareixen amb quatre caps de família, Bernat, Mateu, Ramón i Joan, tot i que no consta que cap d'ells ostentara càrrec de govern algun. ${ }^{5}$

Allò ben cert és que al pare de Bernat li deien Joan i que aquest casà amb una certa Iolant. Ara sabem que aquest casament s'hauria produit abans de 1424 ja que el 8 d'agost d'aquest any Iolant

\footnotetext{
* Aquest treball amplia i en alguns punts corregeix el que vaig exposar en «La carrera eclesiástica como vía de promoción social para las elites rurales. Bernat Fenollar (ca. 1425-ca.1503)» en Valencianos en la Historia de la Iglesia vol. VII. E. Callado (coord.) Facultad de Teologia de València S. Vicent Ferrer, València, 2021, pp. 39-58.

1 Arxiu de protocols notarials del Reial Col legi-Seminari de Corpus Christi de València [APCCV], no. 23.398, protocol de Guillem Ramon Tovia (25-XI-1489).

2 Cal tenir present que aleshores Penàguila, juntament amb les viles de Xèrica i de Llíria i altres llocs estaven estat empenyorades per la corona a la ciutat de València a les darreries del segle XIV per un préstec de 50.000 florins (Vidal 1974: 242-247). El 1404 la reina Maria de Luna acceptava que Penàguila continuara sota la senyoria de la capital fins la restitució de 10.000 florins que restaven de la suma inicial. Arxiu Municipal de València [AMV], Manual de Consells, A-22, f. 242v. y 299v., respectivament. Aquests no foren els únics nuclis que senyorialitzà la ciutat de València (Narbona 2020).

3 El motiu de la lletra missiva era sol licitar l'enviament a la capital del forment que disposés: «Nosaltres havem sabut certament que vós tenits gran quantitat de forment, axí del delme d'aqueixa vila e de son terme com d'altre. Perquè volem he us pregam que non façats contracte ab algú, ans encontinent lo portets o'l façats portar a aquesta ciutat e vendre en l'almodí d'aquella car, ultra que'n haurets for ben covinent, nosaltres vos donarem d'ajuda per cascún cafíç tant com donam als altres per tant forment de consemblants parts, e us farem tantes e tals favors que'n servets ben content. E, axí mateix, si podets fer que alguns altres de la dita vila o circumvehins a aquella porten forment en la forma damunt dita, induhits-los-hi e hauran semblant hajuda aquells qui grossa quantitat n’i portaran. E los traginers quin portaran a cafíços hauran XVIII diners per cafíç. Totes les dites coses vos pregam altra vegada que metats en obra sens falla e tarda e y treballets axí com de vós bé confiam, havent per cert que'ns heu farets assenyalat plaer, lo qual molt vos grahirem e, en son loch e temps, per nosaltres hi serà haüd esguard. E sia en vostra guarda l'Espirit Sant. Scripta en València, a XXVI de setembre any mil CCCC.XII.» AMV, Lletres missives, g3-11, f. 91.
}

4 AMV, Lletres missives, g3-12, f. 142.

5 Arxiu del regne de València [ARV], Mestre Racional, no. 11.781 citat per Guinot (1999: 609-610).

SCRIPTA, Revista internacional de literatura i cultura medieval i moderna, núm. 17 / juny 2021 / pp. 62-85

ISSN: 2340-4841 $\cdot$ doi:10.7203/SCRIPTA.17. 
-ja casada amb Joan- signà una àpoca al rector del lloc de Xirivella -a l'Horta de València-, Guillem Barnús, de 3.300 sous «ratione dotis mee, dicte Yolantis, in bonis dicti Lluís Barnuç, quondam, viri mei». ${ }^{6}$ Podem assumir que Iolant reutilitzà aquest dot per al seu segon matrimoni, la qual cosa ens ajuda a situar la nova unitat domèstica entre els sectors acomodats de la societat rural (Aparisi 2016: 203-205) bo i acceptant que és una xifra que remet als segments intermedis del notariat de la capital (Cruselles, 1999: 288-290). D’altra banda, si Iolant era vídua amb fills no deuríem descartar la possibilitat que aquest fóra també el segon matrimoni per a Joan, perquè resulta estrany que un jove concertara un casament amb una dona més major, més encara en aquests estrats benestants. Una altra referència que suggereix un casament previ de Joan Fenollar és un document molt posterior als fets que estem narrant. En 1490 Mateu Fenollar, fill d'aquest Joan i de Iolant, lliurava a la seua filla Fabiana cinc censals que al seu temps havia rebut del seu pare. Entre els préstecs figurava un de 800 sous de capital i 66 sous 8 diners de pensió que Joan Fenollar «rebé de Bernat Renart, sogre seu, vehí de Dénia». ${ }^{7}$ És cert que aquest 'sogre seu' podria referir-se al pare de Iolant. Això no obstant, em sembla més plausible que aquest Renaut fóra el pare de la primera dona de Joan donat que Mateu no explicita cap tipus de lligam amb ell, per bé que açò darrer -ho reconec- tampoc és concloent.

En qualsevol cas, el matrimoni entre Joan Fenollar i Iolant fa palès els lligams dels Fenollar amb la ciutat de València molt abans que Bernat nasqués i, de fet, el que devia ser oncle seu, Gabriel Fenollar, figurava ja en 1424 ja com a «habitator pro nunch in civitatis Valentie». ${ }^{8}$ Precisament aquest document ens il lustra sobre el nivell econòmic dels Fenollar aleshores ja que l'esmentat Gabriel reconeixia al seu pare, Mateu, haver rebut d'ell 4.000 sous «pro tot illo iure et parte michi pertinenti in bonis vestris racione bonis vestris eidem».?

Aquell mateix any de 1424, Joan Fenollar exercia ja de batle de Penàguila, tot i que no he pogut constatar quan s'inicià en el càrrec. ${ }^{10} \mathrm{Fa}$ la impressió que l'exercici fou vitalici, un fet bastant habitual entre els membres de les elits rurals (Aparisi 2016: 251-257). Les seues fonts d'ingressos, com és habitual entre els sectors benestants del món rural (Menant \& Jessene 2007), anaven més enllà del seu ofici de batle i de notari. Al llarg de la singladura degué atresorar un nivell de riquesa

6 Guillem Barnús és referit com a tutor i curador dels fills del seu germà Lluís, raó per la qual sabem que el matrimoni amb Iolant havia tingut descendència.

7 Archivo de protocols notariales del Real Colegio-Seminario del Corpus Christi de València [APCCV], no. 25.159, protocol de Joan del Port (24-IX-1490). Aquest censal de Renart després de la mort de Mateu Fenollar en 1491 Fabiana, a través del seu germà, el passaria a mans del domer de la Seu.

8 Probablement Gabriel s'hauria traslladat a València anys abans perquè no figura en el morabatí de 1421. APCCV, no. 13.897, protocol de Joan Capdevila (30-XI-1424).

9 Idem.

10 La referencia apareix esmentada en la venda d'un violari que li fan uns musulmans de la Vall de Confrides el 7 d'agost d'aquell any. APCCV, no. 13.897, protocol de Joan Capdevila.

SCRIPTA, Revista internacional de literatura i cultura medieval i moderna, núm. 17 / juny 2021 / pp. 62-85 ISSN: 2340-4841 $\cdot$ doi:10.7203/SCRIPTA.17. 
considerable si tenim en compte que només un dels seus fills -Mateu, com he avançat-va rebre una donació de cinc censals per valor de 3.700 sous de capital. ${ }^{11}$ Finalment, morí el 28 de març de $1447 .^{12}$

Respecte de la família materna de Bernat Fenollar, ja he senyalat que la seua mare havia estat casada amb Lluís Barnús abans d'estar-ho amb el seu pare i que el matrimoni hauria engendrat algun fill. Iolant passaria els anys a venir a Penàguila, fins a la mort de Joan, quan tornaria novament a València. En juliol de 1451, ja aleshores vídua i resident a la capital, nomenava procurador el seu fill Mateu perquè recaptara diverses pensions que se li devien a Penàguila. ${ }^{13}$ Degué morir al voltant de 1454 perquè llavors signà una renúncia sobre l'herència del seu marit en favor dels seus dos fills, Mateu i Bernat. ${ }^{14}$ De fet, gràcies al testament de Bernat lliurat el 1489 (Aparisi, 2020: 250), sabem que Iolant fou enterrada en el fossaret de la Seu, en un vas de la neboda del domer anomenada Vernuça. Donada la similitud d'aquest nom -o malnom més bé- amb el primer home de Iolant -Barnús-, no semblaria arriscat pensar que Vernuça fóra neboda del domer únicament per via materna. El matrimoni de Joan Fenollar i Iolant tingué tres fills, Mateu, Bernat i Margarida. ${ }^{15}$ Mateu passà la major part de la seua vida en Penàguila i sols al final es traslladà també a València, però sense aveïnar-se a la capital, com veurem més endavant. De Margarida les referències són també força escasses, es limiten a una àpoca signada als jurats de la ciutat de Xàtiva per un censal de 299 sous anuals i el seu testament, atorgat el 16 de desembre de 1489, mateix dia que el seu germà. ${ }^{16}$ Un poc abans, el 5 de març, havia nomenat procurador el seu nebot, en segon grau, Perot Fenollar, senyor de Benasau, per recaptar pensions de censal a Penàguila. ${ }^{17}$

\section{Domer i sotsobrer de la Seu}

Bernat Fenollar nasqué a Penàguila, donat que ací és on exercia el seu pare l'ofici de batle i, probablement també, de notari, ja que una tasca no impedia l'exercici de l'altra. El que no sabem

11 APCCV, no. 25.159, protocol de Joan del Port (24-IX-1490).

12 Havia lliurat el testament el 30 de setembre de 1446 al notari Jaume de Sempere, els registres del qual no s'han conservat. Tenim constància gràcies a una referència posterior, de 1491. APCCV, no. 26.399, protocol de Guillem Ramon Tovia (20-IX-1491).

13 Ídem.

14 Tenim constància gràcies a una referència posterior, de 1491. APCCV, no. 26.399, protocol de Guillem Ramon Tovia (20-IX-1491).

15 Martí Grajales esmenta una altra germana Isabel, però, de la que no hi ha cap altra referencia documental (1894: 25).

16 ARV, Protocols, no. 4.244, protocols de Guillem Tovia respectivament 4-XI i 16-XII-1489.

17 APCCV, no. 23.398, protocol de Guillem Ramon Tovia (5-III-1489).

SCRIPTA, Revista internacional de literatura i cultura medieval i moderna, núm. 17 / juny 2021 / pp. 62-85

ISSN: $2340-4841 \cdot$ doi:10.7203/SCRIPTA.17. 
amb certesa és quan va nàixer. Martí Grajales va apuntar que hauria nascut al voltant dels anys 40 del segle XV (1894: 25). Dècades després, donat que Ausias March morí el 1459, Martí de Riquer conclogué que Fenollar hauria nascut a les darreries dels anys 30 a fi de ser relativament jove quan, potser en 1457 o 1458, es produí l'intercanvi poètic entre el senyor de Beniarjó i el futur domer (1964: 321-364). Finalment ha estat Antoni Ferrando qui ha avançat la data de naixement de Fenollar fins al primer terç de la centúria (Colón \& Ferrando 2011: 171). A Penàguila, els primers anys de Bernat transcorregueren entre els camps i l'oficina notarial del seu pare, entre el català espontani dels llauradors cristians i l'àrab dels mudèjars de les alqueries que envoltaven la vila com ara Benifallim o Benilloba.

En un moment imprecís però sens dubte anterior a 1448, Bernat Fenollar ja s'havia establert a València. Aleshores figurava ja com a titular d'un benefici sota l'advocació de sant Felip i sant Jaume en la parròquia de Sant Esteve de la capital. L'esmentat benefici havia estat instaurat per Berenguerona de Ripoll, amb una pensió de 101 sous anuals que el beneficiat rebia de 20 censos diferents. Ultra això, rebia altres 110 sous anuals molt probablement d'algun altre benefici que no apareix esmentat en la documentació (Munsuri 2007: 171-172). La seua integració en els circuits culturals de la capital del regne degué ser fàcil no només per les seues capacitats poètiques sinó també pel pes polític cognom. No devem oblidar que el seu pare era el representant a Penàguila del Consell de València com a titular del senyoriu. ${ }^{18}$ Tot plegat ens ajuda entendre els seus intercanvis literaris amb Ausias March i l'intercanvi de cartes amoroses amb Isabel de Suaris, que sembla que es produí en la dècada dels 50 (Garcia Sempere 2007).

En 1451 Bernat bescanvià el seu benefici de la parròquia de sant Andreu per un altre sota la mateixa advocació en la Seu de València amb el mossèn Pere Andreu. ${ }^{19}$ Així fou com el capellà de Penàguila ingressà en la institució. En 1454 ja figurava, juntament amb Jaume Sorell, com a majorals i clavaris de la confraria de la Verge Maria de la Seu. ${ }^{20}$ Amb tot, aquesta era una responsabilitat modesta si tenim en compte que les confraries de major renom bé per la preeminència social dels seus membres, com ara la de sant Jaume, o bé per la seua creixent devoció entre els sectors populars, cas de la Santa Maria dels Innocents o Desemparats.

18 Anys després, quan la vila de Penàguila retornà al Reial patrimoni, els Fenollar continuaren ostentant el càrrec de batle en el darrer quart del segle XV i primeres dècades del Sis-cents (Mira 2005: 197).

19 El benefici de la Seu havia estat fundat pel prebost i canonge Francesc Davies. Archivo de la Diocésis de Valencia [ADV], leg. 140/001, f. 52.

20 El 30 de gener d'aquell any inventariava els béns de la institució en presència dels oficials que deixaven el càrrec. APCCV, no. 13.897, protocol de Joan Capdevila. Cal no confondre la confraria de Santa Maria dels Ignocents o Desemparats amb aquesta altra. La confraria de Santa Maria de la Seu va ser creada el 1356 per tal d'atendre als clergues pobres. Per això entre els béns inventariats s'esmenta «un matalafet e un coixí per als preveres a soterrar». Tot i que en origen només podien formar part dels preveres, encara que des de 1371 pogueren ingressar els laics també (Martínez Vinat, 2018: 269-279). 
Els càrrecs que procuraven més prestigi i major retribució econòmica estaven relacionats amb la pròpia administració de la Seu. En aquest sentit, Antoni Ferrando ja va assenyalar que Bernat Fenollar exercí el càrrec de domer des de 1461 (Ferrando 2011: 171). Al llarg de tota la seua vida, Bernat fou identificat com a domer, per bé que arribada certa edat degué deixar les seues funcions com a tal. En aquest sentit, el 1491, en un seguit de diversos documents relacionats amb l'herència paterna arran de la mort del seu germà Mateu, el notari Guillem Ramon Tovia altera la formula «domerius Sedis Valentie» amb «alter exdomeriis Sedis Valentie». ${ }^{21}$ Possiblement ja aleshores Fenollar havia deixat d'exercir com a tal però, en qualsevol cas, fins a 1504 encara era referit amb aquest càrrec eclesiàstic.

Tot i que les competències del domer variaven d'una diòcesi a una d'altra, a València era el responsable de cantar la missa de l'alba durant una setmana, alternant-se amb altres els tres domers que tenia la institució. Fins on arribava la perícia musical de Fenollar no ho podem saber però tot sembla indicar que els seus coneixements anaven més enllà de la simple formació en cant pla pròpia dels clergues, tal i com suggereix el fet d'exercir altres càrrecs vinculats a la música. Altres evidències suggereixen aquest lligam amb la música com ara la donació de 70 sous «a la bossa que paga tots jorns les destribucions als capellans en lo cor» en el seu testament lliurat el 1489 i, en el mateix document, la presència entre els testimonis del capellà Antoni Alfageri «qui de present serveix e canta en la eccléssia de Sent Lorenç de la dita ciutat» (Aparisi, 2020: 250). Ambdós fets revelen una vinculació estreta amb el clergat més lligat a la música de la capital del regne. A més, cal tenir present que Fenollar exercí durant tota la seua vida en actiu el càrrec de domer. Altres domers que he pogut identificar són Damià Vinyoles, Jaume Miró i Joan Montesino. ${ }^{22}$ Aquest darrer és amb el qui Fenollar mantingué una relació més estreta com palesa el seu nomenament com a marmessor del testament de 1489 (Aparisi 2020: 250). A més, com el capellà originari de Penàguila, Montesino fou també designat sotsobrer de la fàbrica de la Seu, concretament en les anualitats de 1490 i de $1491 .^{23}$

No tenim massa evidències de l'actuació de Bernat Fenollar com a domer de la Seu. Únicament he pogut constatar que el 28 de setembre de 1473 el capítol manà

als venerables dos domés, ço és, mossèn Vinyoles e mossèn Fenollar, e mossèn Domingo

Torralba, sotsdiaca de la Seu, fesen escriure e notar lo ofici de sant Luís al honrat mestre

21 APCCV, no. 26.399, protocols de Guillem Ramon Tovia (9-X-1491).

22 Damià Vinyoles és probable que fóra parent d'un altre conegut de Fenollar, Narcís Vinyoles, amb, tot i que no he pogut establir el vincle entre els dos Vinyoles. A inicis de 1473 degué patir una forta caiguda que el deixà malferit. Així s'escau d'un document datat el 29 de març d'aquell on el capítol manà fer «una cadira de fust ab cert bastiment faytich al venerable mossèn Damià Vinyoles, domer de la Seu, e açò perquè lo dia de Rams dix lo Passi e per rahó de son accident que no podia star de peus fon feta la dita cadira» per la que hagué de pagar 8 s. Arxiu de la Catedral de València (ACV), vol. 1.483, any 1473, f. 13. De l'altre domer, Jaume Miró hem pogut documentar que el 1479 adquirí «hun libre apellat Mamotret que ha comprat per a la libreria e il lluminar e lligar aquell». Idem, any 1479, f. 26.

23 ACV, vol. 1.483 .

SCRIPTA, Revista internacional de literatura i cultura medieval i moderna, núm. 17 / juny 2021 / pp. 62-85 ISSN: 2340-4841 · doi:10.7203/SCRIPTA.17. 
Nicolau Vallés, scrivent, en que en scriure e notar e en il luminar e ligar costà tot cent-e quatre sous segons los desús dits senyors judicaren, segons consta ab ceda de la mà de mossèn Fenollar. ${ }^{24}$

Si Fenollar, com Vinyoles, havia de supervisar el treball de l'escrivà, podem suposar que alguna formació musical tindrien i el que el de domer no era un càrrec simplement honorífic. En aquest sentit no pot desapercebut el fet que a la casa d'un altre domer, Joan Montesinos, foren enregistrats a la seua mort «una flauta de roure», «un monacord vell» $\mathrm{i}$ « quatre passis notats e ligats cascú per sí ab cobertes de pergamí»». ${ }^{25} \mathrm{Amb}$ tot, no m'estic d'assenyalar que, més enllà del seu gust per la música i la literatura, tots els domers documentats pertanyien a famílies burgeses acomodades com els Fenollar i els Vinyoles. Potser els Montesino resulten més desconeguts però el mateix Joan Montesino lliurà a la seua neboda-neta 6.000 sous per al seu dot, que finalment arribà als 12.000 sous el $1505 .{ }^{26}$

A més d'aquesta, Bernat Fenollar exercí altres responsabilitats en l'administració de la Seu. En abril de 1467 fou nomenat sotsobrer, responsable, per tant, de dur la comptabilitat dels treballs manteniment del temple, reparació de desperfectes i l'adequació dels carrers adjacents. A diferència del càrrec de domer, el de sotsobrer no era vitalici, sinó que era renovat anualment, la qual cosa no impedia ser exercit en diverses ocasions. Fenollar l'ocupà per primer cop en 1467 i després en les anualitats de 1480, 1481 i consecutivament des de 1485 fins a $1490 .{ }^{27}$ Aquest càrrec comptava amb una remuneració anual de 400 sous, una xifra elevada que cobria amb escreix les necessitats bàsiques. ${ }^{28}$

Els assumptes que devia gestionar eren diversos i no tenien a veure únicament amb el manteniment de l'edifici de la catedral. El 2 d'agost de 1486 reconeix al tresorer de la Seu haver rebut 30 timbres d'or (300 sous) «ad opus faciendi scribere breviarium quod de novo fit pro originali breviariorum que stampari debent secundum consuetudinem Valentium et aliarum expensarum eiusdem». ${ }^{29}$ Novament nomenat «viceoperario fabrice dicte Sedis», el 8 de gener de 1489 Fenollar satisfeu 200 sous a Joan Espindelvoguere, «natione alamanus civitatis de Friborch, magister organorum» que la Seu devia pagar per «manufacture et reparationis organorum veterum dicta Sedis». ${ }^{30}$ Alguns setmanes més tard, altres dos alemanys, Joan Besot i Nicolau Clerget, campaners, reconeixien haver rebut del sotsobrer 640 sous «pretio campane vocate la Vedada per eos facte et de duobus solidis per quadam libra que pensit». ${ }^{31}$

24 ACV, vol. 1.483, any 1473, f. 13.

25 APCCC, no. 26.408, protocol de Guillem Ramon Tovia (24-IX-1505). Esmentat per Villanueva (2017: 20).

26 APCCC, no. 26.409, protocol de Guillem Ramon Tovia (28-XI-1504).

27 ACV, vol. 1.484.

28 ACV, vol. 1.484, any 1481, f. 28v.

29 ACV, vol. 3.684. Protocol de Jaume Esteve.

30 ACV, vo. 3.685.

31 Idem (1489-III-30).

SCRIPTA, Revista internacional de literatura i cultura medieval i moderna, núm. 17 / juny 2021 / pp. 62-85 ISSN: 2340-4841 · doi:10.7203/SCRIPTA.17. 
Per aquestes dates, com veurem, València patia un fort brot de pesta, raó per la qual molts canonges - entre d'ells probablement el mateix Fenollar- traslladaren la seua residència fora de la ciutat. És per això que el 14 d'abril de 1490 diversos canonges «congregats dins lo castell de Burgaçot, celebrant capítol de la Seu de València» signaren l'àpoca pertinent al «venerable mossèn Bernat Fenollar, prevere, sotsobrer de la dita Seu, present, tres mília sous de la quantitat que era tornador del seu compte» ja que aquell mes acabava el seu exercici en l'esmentat càrrec. ${ }^{32}$ Encara el 17 d'abril d'aquell any pagava al pintor Martí Torner 157 sous 6 diners per 750 pans d'or, a raó de 21 sous per centenar, «per a la himatge de sent Christòfol» e altres 100 sous «per mans de la pintura e daurar e de colan» $\mathrm{i}$ al fuster Antoni Peret 80 sous «per fusta e mans e de posar la ymatge de sent Christòfol en son loch». ${ }^{33}$ La liquidació definitiva dels comptes es va produir el 17 de setembre quan Montesino, que l'havia substituit al capdavant del càrrec li signà l'apoca de 594 sous 9 diners i òbol com a fi del seu exercici. ${ }^{34}$

Per una altra banda, a més de sotsobrer i domer, ara sabem que Fenollar exercí una altra responsabilitat en l'administració de la Seu. Entre el maig de 1471 i l'abril de 1473, Fenollar exercí de 'col lector dels terços de benifets dels absents'. Sembla ser que els titulars de beneficis en la Seu que s'absentaven havien de lliurar un terç del valor de la renda a la institució per finançar «lo ofici, enramada e scolans» per suplir-los el dia de l'advocació. ${ }^{35} \mathrm{Al}$ col lector corresponia recaptar l'esmentat pagament dels titulars i pagar les despeses de la celebració.

Aquestes són, en l'estat actual de les investigacions, els càrrecs que exercí Fenollar en l'administració de la catedral, tot i que no hem de descartar que en el futur apareguen noves informacions donat el llarg període que el domer estigué vinculat a la institució. En aquest sentit, el 19 de febrer de 1487 el domer acordà amb Jaume Díxer, un prevere doctor en Decretals, sotmetre's tots dos a una arbitració «super presentationem ac iuris collationem fienda de quondam beneficio in Sede Valentie sub invocatione Sancti Bartholomeo et eius capella per nobilem Elicsendam de Romaní instituto». ${ }^{36}$

Els arbitres escollits -Bernat Saïdia, doctor en decretals, i Pere Sanç, prevere, beneficiat en la Seu de València-, acceptaren el nomenament. El resultat de l'arbitració, però, no s'ha conservat. Les responsabilitats eclesiàstiques $-i$ les fonts d'ingressos que se'n derivaven d'elles- anaven més enllà dels murs de la Seu. A Alzira, a l'església de Santa Caterina, Bernat Fenollar era titular del benefici de Sant Esteve a les darreries dels 80 . Ho sabem perquè el 3 de febrer de 1487 nomenà procuradors Joan Sanç i Francesc Roig, tots dos capellans de la vila, perquè recaptaran els diners del benefici. ${ }^{37}$

32 Idem. Cal tenir en compte que llavors Burjassot era un dels dominis del Capítol de la Seu.

33 Idem.

34 Idem.

35 ACV, Vol. 4.039 año 1471, f. 21.

36 SNAHN, OSUNA, C.1307 D.0006.

37 ARV, Protocols, no 3.205, protocol de Joan Fenollar.

SCRIPTA, Revista internacional de literatura i cultura medieval i moderna, núm. 17 / juny 2021 / pp. 62-85 ISSN: 2340-4841 · doi:10.7203/SCRIPTA.17. 
D'altra banda, segons el registre de l'Escrivania major de ració del rei conservat a l'Arxiu de la Corona d'Aragó, el 23 de setembre de 1479 cert mossèn Bernat Fenollar fou nomenat com a «capellà e mestre de la capella» de Ferran II. I encara el desembre del mateix any com a «lloctinent d'almoiner». ${ }^{38}$ Tradicionalment, aquest personatge s'ha identificat amb el nostre biografiat, tot i que el document es refereix a Fenollar com «natural de la ciutat de València e beneficiat en la Seu de la dita ciutat». No es fa esment, per tant, de la seua condició de domer, càrrec pel qual era conegut entre els seus contemporanis i que apareix reflectit sempre en la documentació. Ultra això, cal tenir en compte que a l'any següent, en 1480, Fenollar seria nomenat sotsobrer de la Seu de València, un càrrec que requeria de la seua presència en la ciutat. Així les coses cabria plantejar-se dues possibilitats: o bé el Fenollar mestre de capella no es correspon amb el nostre biografiat, sinó amb un parent homònim -potser el seu nebot homònim que apareix al testament de 1489 i que no fou domer de la Seu- o bé, com apunta Villanueva, aquest fóra un nomenament purament nominal i de reconeixement, sense que implicara l'exercici real de les funcions inherents al càrrec (2017: 11).

Finalment, les seues obligacions eclesiàstiques comportaven també alguns serveis personals a particulars, prova del reconeixement que li atorgaven seus contemporanis. En aquest sentit, Bernat Fenollar degué actuar com a marmessor en més ocasions de les que la documentació ha permès constatar fins ara. A més de la seua mateixa germana, la vídua del cavaller Jaume Perfeta, de nom Bartomeua, el nomenà un dels seus marmessors en el seu testament, juntament amb fra Llop, prior del convent de Carme de València, el $1479 .{ }^{39}$ Ho sabem perquè, alguns anys més tard, el 3 de febrer de 1487 el domer de la Seu inventarià els béns que la difunta havia deixat per a la «sancta creuada», un terme que, per la seua cronologia, podríem vincular més aviat a la Inquisició que no al fenomen de les croades. ${ }^{40}$ Encara a mitjans d'aquell any el documentem fent pagaments als beneficiaris del testament de la vídua. ${ }^{41}$

L'exercici de tots aquests càrrecs i nomenaments procuraven a Fenollar sucosos ingressos. En aquest sentit, és probable que la marmessoria abans esmentada tingués la seua pertinent retribució econòmica. Ultra això, a més dels 400 sous anuals del seu càrrec de sotsobrer els anys que l'exercia calia afegir els 211 sous pel benefici a la catedral i el que ingressava pel benefici a l'església de santa Caterina d'Alzira, que no apareix reflectit a la documentació. A més dels derivats dels seus treballs com a eclesiàstic, Bernat Fenollar comptava amb altres fonts d’ingressos. En aquest sentit, tot i que

38 ACA, Reial Patrimoni, Mestre Racional, Sèries Generals A, vol. 939bis, f. 173v. citat per Vicens Vives (2006: 669), Ferrando (1983: 171-172) i Villanueva (2017: 11).

39 APCCV, no. 22.0059, protocol de Joan Molina.

40 De fet, els béns enregistrats els podem considerar l’instrumental per a la celebració de la Eucarístia, com ara «Ítem, hun cofre gran, fet a manera de altar portàtil ab sos peus. (...) Ítem, una capsa de stolar hòsties nova, dins la qual fon atrobat hum plom cobert de vermell per a emprensar les dites hòsties (...) Ítem, hum missal votiu de pergamí, quasi nou, amb gafets e gafes de argent, cobert ab coberta de tela blanqua obrada ja vella (...)». Ídem.

41 APCCV, no. 22.0059, protocol de Joan Molina (11-VII-1487).

SCRIPTA, Revista internacional de literatura i cultura medieval i moderna, núm. 17 / juny 2021 / pp. 62-85 ISSN: 2340-4841 · doi:10.7203/SCRIPTA.17. 
no podem precisar el volum que representaven, sí que és cert que les activitats creditícies no li eren alienes. En maig de 1457, «beneficiatus in Sede Valentie sub invocatione sanctorum Philippli et Iacobi» - llavors encara no havia estat nomenat domer-, signà un àpoca de 700 sous pel quitament d'un violari de 100 sous de pensió al fuster de València Bernat Tarroja. ${ }^{42}$ El 16 de juny de 1497 el seu company domer Joan Montesino li vengué un violari «ad vitas vestri, dicti emptoris, et dompne Alduncie [...] beata» de 200 sous anuals per 1.400 sous de capital. ${ }^{43}$

A més de les inversions creditícies, Fenollar comptava amb ingressos que provenien del lloguer d'immobles. Sabem que disposava d'un immoble que probablement estava situat a la mateixa plaça de la Seu i que el 1486 estava llogat a Damiata Mauler per un cens anual 160 sous. ${ }^{44}$ És possible que fóra el mateix immoble que el 1489 tenia arrendat al canonge Jordi de Centelles i que li procurava 22 sous anuals, una summa més aviat insignificant en el conjunt de la seua economia, però que ens il lustra sobre la diversitat de les fonts d'ingressos que cercava el capellà. ${ }^{45}$ Anys més tard, el

42 APCCV, no. 16.840, protocol de Joan Navarro (20-V-1457).

43 APCCC, no. 26.404, protocol de Guillem Ramon Tovia.

44 APCCC, no. 22.060, protocol de Joan de Molina (2-X-1486).

45 Ho sabem perquè el mateix Fenollar ho esmenta al seu testament. Jordi de Centelles, fill del comte d'Oliva Francesc Gilabert de Centelles. A més de les tasques pròpies de la seua condició de capellans, tots dos compartien afició per la literatura. De fet, Centelles participà en els certàmens literaris de 1456, en l'organitzat pel mateix Fenollar en 1474 i encara en 1486, on també participà el nostre biografiat. De la seua vida privada, sabem que estigué involucrat en diversos afers violents a València i Xàtiva (Ferrando 1983: 115-122 i 380-388). Com a conseller reial (Vicens Vives 2006: 592), Ferran el Catòlic perquè aquest requerí de la seua presència en la cort, com s'escau del següent document. En bona lògica, la casa esmentada en el document devia de ser la que havia llogada a Bernat Fenollar.

Anno a Nativitate Domini $M^{\circ}$.D.CCC.LXXXVIII ${ }^{o}$ die vero intitulata XXIII ${ }^{a}$ mensis octobris.

Constituhit en presència del notari e testimonis davall scrits lo noble don Jordi Centelles, canonge de la Seu de València, dins la casa sua, la qual aquell té en la ciutat de València, en la plasa vulgarment nomenada de la Seu, jahen tot nu en hun lit dins una cambra de la dita casa. Et verbo dix que com ja aquell en lo dia de despús ahir dimarts, comptat XXI del present e dejús scrit mes per lo magnífich mossèn Luís de Cabanyelles, cavaller, conseller e camarlench de la magestat del senyor rey e governador del present regne de València, li fos estada presentada una lletra de sa reyal magestat en paper scrita e ab sagell secret de sa reyal senyoria (...) e dins és del tal tenor:

'Lo rey.

Don Jordi Centelles, nós vos havem mester parlar per fets e coses que consernexen molt lo estat e servey nostres. E, per tant, vos manam molt secretament que, decontinent rebuda la present, partixquau e vingau a nós perquè us pugam parlar les dites coses e guardar per res no haja falla o dilació alguna, si lo nostre servey vos és car. De Valladolit, a XXIIII de setembre any $\mathrm{M}^{\mathrm{i}}$ CCCC LXXXVIII. Yo el rey. (...)'

Lo qual dix que era prest prompte e per aparellar obehir la magestat del senyor rey e los manament de aquell, emperò, que per la indisposició de sa persona com stigués en lo dit lit de mal de pedra e arenes, e no en punt de cavalcar ne de metre's en camí e, si u feya, la vida sua perilava tant que creu que bastaria a matar-lo. E que puix lo magnífic mestre Ferrer Torrella, mestre en arts e medicina, era present, lo qual lo visitava del dit mal e accident de mal de pedra, que requeria a mi, dit notari, que rebés informació de aquell en quina dispoció stava e que així de la relació de aquell com de la indisposició stava e que axí de la relació de aquell com de la indisposició sua li rebés carta o cartes públiques.

Et eodem instant, lo dit mestre Ferrer Torrella, mestre en arts e medicina, dix que per quant ell visitava lo dit noble don Jordi de Centelles del mal de arenes e pedra per lo qual jahia en lo lit, que no era lo seu mal tal que ell se pogués metre en camí

SCRIPTA, Revista internacional de literatura i cultura medieval i moderna, núm. 17 / juny 2021 / pp. 62-85

ISSN: 2340-4841 $\cdot$ doi:10.7203/SCRIPTA.17. 
1502 el documentem venent un altre immoble diferent d'aquest. Es tractava d'una casa situada «in parrochia sancti Andree prope pontium nuncupatum de les Ànedes» que vengué a la vídua de Joan de la Fos per 280 sous i que estava carregat amb certs censos. ${ }^{46}$

D'altra banda, fa unes dècades, Jordi Ventura va suggerir que Bernat Fenollar havia estat relacionat amb el Sant Ofici i que fins i tot havia declarat com a testimoni en un procés (Ventura 1978: 146). Això no obstant, $\mathrm{i}$ admetent que no he pogut localitzar el document que esmenta Ventura -perquè no hi anota la pertinent referència arxivística-, sospite que el Fenollar que declarà davant el Sant Ofici no era el domer de la Seu sinó més bé el seu nebot homònim. Això explicaria perquè el testimoni hagué d'allotjar-se a casa del notari Joan Fenollar, germà seu, quan vingué de Xàtiva a València. Res sembla suggerir que el domer de la Seu hagués estat a Xàtiva ni que tingués, com Ventura li atribueix producte de la confusió amb el nebot homònim, cap experiència docent. Així les coses i a la llum que sobre el Sant Ofici s'han realitzat en els darrers anys, el domer Fenollar no hauria tingut cap vincle formal amb la Inquisició. Si bé ho mirem tampoc ens hauria de sorprendre això. Fenollar tenia un ampli ventall d'amistats i coneixences entre els conversos amb els que compartia aficions literàries i interessos econòmics com ara Joan Ram Escrivà i de tant en tant requeria els seus serveis com el notari Joan Molina.

\section{Els testaments dels germans Fenollar}

A les darreries de 1488 i inicis de 1489 s'estengué pel migjorn del país un nou brot de pesta. ${ }^{47}$ Les mesures que les viles prengueren per frenar la seua expansió foren del tot inútils i a les darreries de gener d'aquell any la glànola arribà a la ciutat de València que havia penetrat des de les terres de Múrcia. Lluny de ser un simple brot, l'episodi es convertí en una epidèmia fortament virulenta que, segons alguns testimonis, en el seu punt àlgid arribà a matar més de 140 persones en un sol dia (Rubio 1994-1995: 1.216. Ferrando 1999: 77-81). Els pitjors moments es visqueren en els mesos de març, abril i maig de 1490, quan començà a decréixer el nombre de morts fins que en agost es donà per eradicada.

En aquest sentit, no foren pocs els que, davant el perill de mort, decidiren deixar constància de les darreres voluntats. Fou el cas d'alguns coneguts de Bernat Fenollar com ara els beneficiats de

e si u feya que la vida sua passava molt perill e que no u poria sostenir la persona sua cavalcar ne anar a cavall com lo mal no lo y permetria. E açò és lo que segons la consciència sua ell veu e pot veure en aquest feyt e malaltia.

De totes les quals coses requés a mi, Jeroni Tovia, notari, ésser li feta carta pública. Presents foren per testimonis los nobles Olf de Pròxida e lo venerable Jheroni Fuster, prevere beneficiat en la Seu, habitants de València.

ACCV, no. 24.996, 24-X-1488. Aquesta mena de peritatges mèdics no eren un fet estrany a la València medieval (Ferragud, 2018).

46 ACV, Pergamins, no. 7.167.

47 Arxiu municipal d'Alcoi, Manuals de Consell, vol. 4, f. 81.

SCRIPTA, Revista internacional de literatura i cultura medieval i moderna, núm. 17 / juny 2021 / pp. 62-85

ISSN: 2340-4841 $\cdot$ doi:10.7203/SCRIPTA.17. 
la seu Miquel Calbet i Joan Roger, ${ }^{48}$ el també canonge de la seu Guillem Serra (Guia 2003) i el conegut Narcís Vinyoles (Ferrando 1978. Guia 2003). En el marc d'aquesta pandèmia, el metge d'origen convers Lluís Alcanyís escrigué el seu tractat Regiment de la pestilència, bo i acudint a l'oficina d'un notari per lliurar el seu testament (Arrizabalaga, 2008: 53-55. Aparisi 2020b: 7). Entre els personatges coneguts que perderen la vida s'hi trobaven l'esmentat Guillem Serra (Guia 2003), Joan Pelegrí, ${ }^{49}$ sor Isabel de Villena, el canonge Maties Mercader (Ferrer 1987-1988) o el bisbe de València -en substitució de Roderic de Borja a Roma- Jaume Peres.

Així les coses, no deuria sorprendre'ns que els tres germans redactaren els seus respectius testaments. El primers en fer-ho foren Bernat i Margarida acudien a l'oficina de Guillem Tovià, el 16 de desembre. Una setmana després ho faria Mateu, el 25 de desembre, amb un altre Tovià, Guillem Ramon. ${ }^{50}$ En el seu testament, Mateu reconeixia ser «natural e vehí de la vila de Penàguila, habitant de present en la ciutat de València» i nomenava marmessor el seu fill Bernat. ${ }^{51}$ Demanava ser soterrat «de nit e ab les menys cirimònies que fer se puixa» «en aquell vas a hon jau la honorable na Yolant Fenollar, mare mia, lo qual vas stà en lo fossaret de la insigne Seu». A més de la restitució del dot de la dona Isabel Sisternes, que havia estat de 7.500 sous més altres 3.750 de creix, deixava la legítima de 5 sous als seus fills Joan, Miquel, Tomàs i Fabiana Fenollar i nomenava hereu universal l'esmentat Bernat. Finalment Mateu moriria gairebé dos anys després, el 17 de desembre de 1491. Per part seua, Margarida es limitava a nomenar marmessor i alhora hereu universal Bernat, «germà meu de pare e mare» i demanava ser soterrada «en aquell loch o vas que és dins lo fossaret de la seu de València, en la qual ma mare e altres de la mia parentela són stats soterrats» (Aparisi 2016: 417-419).

Prou més extens era el testament de Bernat (Aparisi 2020a). En ell, nomenava hereva universal a Margarida però escollia el domer Joan Montesino com a marmessor, tot fent-li donació de 50 sous «per caritat e $\mathrm{n}$ recompensa de sos treballs». Com la seua germana demanava ser sebollit «en lo vas de ma neboda Vernuça, muller de present d'en Pere Tarragó, en lo fossaret de la dita seu, on jau e reposa ma mare e nebodes». Per tant, els tres germans demanaven ser sebollits en la mateixa

48 APCCV, no. 19.129, protocols de Antoni Julià, respectivament 15-III y 15-V-1490.

49 Pelegrí ARV, Protocols, no. 2.171. Morí abans de l'1 d'octubre de 1490, quan se subhastaren alguns dels seus béns.

50 Aquest notari devia ser fill de l'anterior, tot i que no he pogut establir el vincle. La relació dels Tovia i els Fenollar probablement devia ser resultat de la coneixença entre Francesc Tovia, germà de Guillem el notari, i Bernat Fenollar tots dos preveres beneficiats a la Seu. A més, Bernat Tovia, germà dels altres dos Tovia esmentats, era un dels apotecaris que proveïen de ciris i cera la Seu. APCCV, no. 19.129, protocols de Jeroni Tovia (9-X-1481). Amb tot, cal dir que tampoc els Tovia foren els notaris habituals dels Fenollar, per bé que que els protocols de Guillem Tovia estan bastant malmesos, raó per la qual no podem descartar que els Fenollar acudiren a la seua notaria en més ocasions de les que hem pogut constatar. De fet, cert Mateu Fenollar, paraire i veí de Penàguila, per tant, molt probablement germà del domer de la Seu, nomenà procurador el notari Guillem Tovia el 22 de novembre de 1465 (APCCV, no. 24.136, protocols de Joan Verdanxa). Margarida únicament consignà amb Tovia aquest document i una àpoca de 299 sous signada als jurats de Xàtiva per la pensió d’un censal. ARV, Protocols, no. 4.244, protocols de Guillem Tovia (4-XI-1489).

51 APCCV, no. 26.398, protocols de Guillem Ramon Tovia (16-IX-1489).

SCRIPTA, Revista internacional de literatura i cultura medieval i moderna, núm. 17 / juny 2021 / pp. 62-85 ISSN: 2340-4841 · doi:10.7203/SCRIPTA.17. 
fossa, junt a la mare, un fet que des de l'òptica de la història de les mentalitats i de les emocions no deuríem deixar passar desapercebut. Però si alguna cosa paga la pena destacar del testament de Bernat Fenollar és la donació a persones i institucions concretes d'un conjunt de llibres.

\section{La biblioteca de Bernat Fenollar}

En el seu testament, Bernat Fenollar disposa d'un total de setze volums que havien de ser lliurats pel marmessor als seus nebots Bernat i Fabiana i a la Seu de València. Més enllà dels beneficiaris i dels llibres en concret, que tot seguit analitzaré, aquesta pràctica de disposar dels artefactes quotidians com si de béns immobles es tractara traspua una afecció cap a ells que traspassa el seu valor econòmic. I, en realitat, el material turn (Downes, Halloway and Randles 2018) que ha experimentat la historiografia en la darrera dècada posa de manifest que aquesta pràctica era molt més habitual del què se n’havíem adonat, particularment entre els individus benestants (Cohn 2012).

Si els setze volums que apareixen esmentats en el testament constituien la totalitat de la seua biblioteca no ho podem saber però sembla raonable pensar que aquesta devia ser bastant més amplia donada la seua condició de lletraferit. A més, resulta realment modesta si la comparem amb les biblioteques d'altres canonges com la de Francesc d'Arlés o Lluís de Capmanyes, amb vint-i-tres i quaranta-tres volums, respectivament (Ferrer 1993: 139-141). També trobem biblioteques de majors dimensions entre els beneficiats com Pere Dorcal, mort en 1419, que tenia trenta-tres volums (Ferrer 2016: 289290). Però sobretot queda molt lluny de la del canonge Maties Mercader, mort com he dit el 1489, que comptava amb dos-cents cinc exemplars (Ferrer 1987-1988. Ventura 1978: 37-38 i 131-132).

El conjunt de llibres que esmenta Fenollar en el seu testament es caracteritza per la seua homogeneïtat, amb la teologia com a temàtica central, un fet, per altra banda, gens estrany en les biblioteques de clergues (Ferrer 1993: 140). Els beneficiaris de la seua donació són els seus nebots Fabiana i Bernat, i la biblioteca de la Seu. ${ }^{52}$ En concret, «per obs de crèxer la libreria» lliurava

sis volums de libres, ço és, una Bíblia gran, hun Mestre de Sentències, tot tocat de mà de mestre Francesch Eximènez, la Última de sent Thomàs, e les Obres de Sèneca, les Epistoles de Ceprià màrtir e los Sermons de Lleó papa. Los quals sis volums vull per lo dit marmessor sien presentats e donats als reverents senyors del Capítol per a dita libreria ad bonum comunne (Aparisi 2020a: 250).

\footnotetext{
52 No era un fet estrany que els canonges i beneficiats deixaren llibres a la biblioteca de la Seu. Maties Mercader lliurà les Collaciones de Joan Cassiani (Ferrer 1987-1988: 453), Guillem Serra establí «que si los senyors de canonges e Capítol voldran alguns dels altres libres meus per a la dita Seu, que aquells libres que dira e elegira lo reverent mestre Melchior Miralles, mestre en sacra theologia, sotssacrista de la dita Seu, en sien donats e liurats a la dita Seu, lexant-ho tot a eleccio e voluntat del dit mestre Melchior Miralles» i a més, deixà «a la dita Seu de València los quatre volums dels libres que yo tinch del Cristiaà dels quals yo he prestat la hu al reverent mestre Conill e l'altre al honorable en Jaume Aguilaniu». APCCV, protocols de Bartomeu de Carries, núm. 22.450 (7-III-1489) citat per Guia 2003 i Rodrigo 2016.
}

SCRIPTA, Revista internacional de literatura i cultura medieval i moderna, núm. 17 / juny 2021 / pp. 62-85 ISSN: 2340-4841 · doi:10.7203/SCRIPTA.17. 
Dels sis volums, només el referit com Obres de Sèneca no és de temàtica religiosa. Això no obstant, la seua presència en una biblioteca religiosa estaria justificada perquè, tot $i$ ser un autor pagà, fins ben avançat el segle XVI, es considerava que, probablement, Sèneca s'havia convertit al cristianisme en secret. Ultra això, el pensament estoic de Sèneca -que entenia la divinitat com una unicitat i estava més prop, per tant, del monoteisme cristià que no del politeisme pagà- fou integrat en el cristianisme pels Sants Pares, particularment per Sant Jeroni. De fet, encara a les darreries del segle XV circulava una breu col lecció de cartes entre Sèneca i Pau -Epistolae Senecae ad Paulum et Pauli ad Senecam- que probablement estarien incloses en aquest volum, per bé que ja aleshores Lorenzo Valla havia demostrat la falsedat d'aquestes epístoles (González 2014).

Els «Sermons de Lleó papa» i «la Última de sent Thomàs» són volums bastant habituals ja que els documentem també en la biblioteca del canonge Maties Mercader (Ferrer 1987-1988: 453). Les «Epistoles de Ceprià màrtir» es refereixen a Cebrià de Cartago mentre que amb un «Mestre de Sentències» podria referir-se al Libri Quatuor Sententiarum o Quatre llibres de sentències confegit per Pere Llombard. En ell, l'autor reunia passatges bíblics i els comentaris que d'ells feien els Pares de l'Església. Fou text força utilitzat en els estudis de teologia fins ben entrat el segle XVI.

A més de la biblioteca de la Seu, els receptors dels llibres de Bernat Fenollar foren els seus nebots, Fabiana i Bernat, tots dos fills del seu germà Mateu. A Fabiana li feia donació «perquè ls tinga e liga en memòria mia» de dos volums, «lo Primer del Crestià de mestre Francesch Eximènez, e lo Boca $^{53}$ de Consolació, abduy en pla» (Aparisi 2020a: 250). Tots dos resulten de fàcil identificació ja que es tracta de textos que circularen intensament en l'Europa medieval. El darrer correspon al De consolatio philosophiae o Llibre de consolació de Filosofia, escrit per Boeci durant el seu captiveri, en les primeres dècades del segle VI. L'autor conversa amb Filosofia que mitjançant el diàleg l'instrueix sobre la verdadera saviesa i la providència. El text original en llatí fou traduït al català, com fa notar el mateix Fenollar. Tot i que fra Pere Saplana la traduí en la primera meitat del segle XIV, la versió que acabaria imposant-se -i que probablement és la que Fabiana rebia- és la traducció que féu fra Antoni Ginebreda en la segona meitat de l'esmentada centúria (Cifuentes 2006: 184-188). L'altre text, com és sabut, forma part de l'extensa obra que Eiximenis no arribà a completar, Lo Crestià. El Primer, dedicat a l'ètica cristiana, fou imprès a València el 1483, tot i que en aquest cas no s'especifica si es tracta d'un exemplar manuscrit o d'impremta (Cifuentes 2006: 171-172).

La resta de llibres, la meitat dels setze volums que integraven la seua biblioteca, Fenollar els deixa al seu nebot homònim. Són «lo Manipulus clericorum, part del Racional, hun volum [de] Petrarcha, De remediis utriusque fortunae, Stimulus amoris de Bonaventura ab alicet tractats, lo Vita Christi eiusdem, e lo Forma noviciorum e hun volum de Qüestions ab molts tractats, après cubert ab plaçons en quatre cartes de full. E aquests reeba ab bona amor, pregant Déu per la mia ànima» (Aparisi 2020a: 250). Cal tenir present que aleshores el jove Bernat Fenollat era «simple tonsurat», la qual cosa explica

53 Sic llegiu «Boeci». 
la donació d'aquests llibres, amb un marcat caràcter formatiu. ${ }^{54}$ En aquest sentit, tant el Manipulus clericorum com el Forma noviciorum eren textos que es feien servir en la formació dels novicis, tot $\mathrm{i}$ que tampoc eren estranys en les biblioteques de clergues d'edat més avançada. ${ }^{55}$ El Stimulus amoris era un altre text habitual en les biblioteques pròpies d'homes d'església i institucions eclesiàstiques, igualment com els anteriors amb un component formatiu. ${ }^{56} \mathrm{~A}$ l'edat mitjana aquest text era atribuït, com fa el mateix Bernat Fenollar, a Bonaventura de Bagnoregio, franciscà professor de la universitat de París en les dècades centrals del segle XIII. Tanmateix, aquest i altres textos han estat agrupats sota la denominació Pseudo-Bonaventures per referir-se a un conjunt de textos doctrinals i formatius per als novicis. De fet, una de les parts que integren aquest Stimulus amoris és la Instructio sacerdotis ad se preparandum ad celebrandum missam. Cal fer notar que en el volum que posseïa Fenollar hi havia altres tractats tot i que sense precisar-ne el seu contingut.

L'altre llibre que el domer atribueix a Bonaventura és el Vita Christi, nom amb el que va ser conegut les Meditationes Vitae Christi, però, com en el cas anterior, està considerada actualment també un Pseudo-Bonaventura, si bé el seu autor podria ser un franciscà. Per concloure, posseïa també el De remediis utriusque fortunae de Francesco Petrarca, una obra en la que, novament sota la forma de diàleg, l'autor propugnava la necessitat de mantenir la determinació davant els infortunis. El volum referit com una «part del Racional» potser devia tractar-se del Rationale divinorum officiurum, un tractat escrit per Guglielmus Durand al segle XIII sobre el simbolisme del ritus cristià que també posseïa Maties Mercader (Ferrer 1987-1988: 451). Endemés Fenollar lliurava al seu nebot «hun volum de Qüestions amb molts tractats» que no he pogut identificar.

\section{Assumptes de família}

Més enllà de les seues aficions literàries -en 1486 participà novament en un certamen poètic dedicat a la Immaculada Concepció (Ferrando 1983: 387)-, i de les seues obligacions com a clergue de la Seu de València, Bernat Fenollar actuava com a procurador en la capital del regne de la seua parentela. En aquest sentit, poc o molt, Bernat degué facilitar la inserció del seu nebot Joan Fenollar, que treballa com a notari dins els murs de la ciutat a partir de mitjans dels anys 80. Tot i el lligam familiar, el ben cert és que Bernat no sovintejà l'oficina del seu parent i, a excepció de d'un parell

\footnotetext{
54 Ho sabem perquè així s'especifica en el nomenament que li fa el notari Joan Fenollar com a procurador seu, el 4 de març de 1490. ARV, Protocols, no. 2.171.

55 Així per exemple els canonges Joan Trullols, mort el 1411, i Francesc Daries, mort el 1440, posseïen un exemplar (Sanchis 1999: 89 i 95 respectivament).

56 La biblioteca de la Seu en 1418 posseïa un exemplar, com també els canonges Francesc Daries, ja esmentat, i Antoni Bou, mort el 1461. (Sanchis 1999: 140, 95 i 96 respectivament).
}

SCRIPTA, Revista internacional de literatura i cultura medieval i moderna, núm. 17 / juny 2021 / pp. 62-85 ISSN: $2340-4841 \cdot$ doi:10.7203/SCRIPTA.17. 
de documents el 1487 ja esmentats, ${ }^{57}$ únicament registrà amb ell els actes jurídics que implicaven la família del mateix Joan. ${ }^{58}$

Entre els individus d'aquesta branca amb els que Bernat mantingué una relació més estreta hi destaca Perot Fenollar. Abans de 1487, Perot, que havia estat batle de Penàguila fins aleshores, marxà a Nàpols. Ací entrà al servei de l'ambaixador de Ferran II, i anteriorment mestre racional del regne de València d'origen convers (Ventura 1978: 156-162), Joan Ram Escrivà de Romaní, per intermediació de la mateixa reina, Joana d'Aragó (Parisi 2003-2004: 212-213). Això no obstant, no podem obviar l'amistat que unia Escrivà de Romaní i el mateix Bernat Fenollar, la qual explica les gestions que l'ambaixador féu en favor de l'esmentat Perot. ${ }^{59}$

A grans trets, però, desconeguem els detalls de la relació entre Bernat i Perot. Únicament tenim testimonis parcials que confirmen que el domer actuava a València com a representant del seu parent. El 8 d'agost de 1487, la mare de Perot nomenava procurador el seu fill Lluís «ad recipiendum et petendum ab honorabile Bernardo Fenollar, domerio sedis Valentie, duodecim libras quos honorabile Petrus Fenollar, residens in civitate Neapolis, filius meus fraterque vestri, dicti Ludovici, cum suis literis iussit michi dari per dictum Bernardum Fenollar». ${ }^{60}$ Posteriorment, el 21 de novembre de l'any següent el domer de la seu comprà, en nom del seu parent, l'alqueria d'Alcoleja -un petit senyoriu amb unes 8 famílies musulmanes el 1510 en el terme general de Penàguila (Valldecabres 2002: 336)- a Francesc Martí de Xàtiva per una summa que superava els 28.333 sous. ${ }^{61}$ A més, Bernat comprà del mateix Martí dos censals que sumaven 8.800 sous. $^{62}$

57 Un és la procuradoria del 3 de febrer, l’altre, el compromís d’arbitració del 19 del mateix mes. Cf. nota 27 i 28 respectivament.

58 Tot i el trasllat de Joan Fenollar a València, la comunicació i la relación amb Penàguila fou constant al llarg de tota la vida. Així, per exemple, el 6 de desembre de 1493 la universitat de Penàguila el nomenava síndic. Arxiu parroquial de Penàguila, no. 235, protocol de Pere Romana.

59 En aquest sentit, a més de les evidències que se'n deriven dels textos literaris, en una de les cartes del bisbe de Sogorb, Bartomeu Martí, a Joan Escrivà de Romaní datada en maig de 1488 es fa referència a «l'estament de la causa del benifet de mossèn Fenollar. Estich maravellat [deia] que de dos coses [l'altra era la salut del seu fill] que importaven tant, vós siau tardat en lo respondre». A què es referia amb el 'benifet de mossèn Fenollar' no ho sabem amb seguretat però probablement es refereix a la disputa que el domer mantenia des d'un any abans amb el mossèn Jaume Díxer pel benefici de la família Romaní, donat que es tractava de la mateixa família -els Romaní- i la proximitat de les dues dates (Parisi 2006-2007: 115-116).

60 ARV, Protocols, no. 3.205, protocols de Joan Fenollar.

61 Donada la coincidència del cognom i de la procedència, no deuríem descartar la possibilitat que aquest Francesc Martí fora parent del bisbe de Sogorb, l'esmentat Bartomeu Martí, que aleshores estava integrat en el servei de Roderic de Borja com a preceptor dels seus fills. Aquest Bartomeu també tenia al seu càrrec el fill de Joan Escrivà de Romaní $i$ Ram, que, com ja ha estat dit, era amic íntim de Bernat Fenollar.

62 «a 'n Francesch Martí de Xàtiva per part del preu de Alcoleja, vint-huit mília tre-cents trenta-tres sous quatre diners segons se mostra ab carta rebuda per lo notari davall scrit a vint-e-hú de noembre any LXXXVIII. Ítem, al mateix en 
Tot i la intensitat de la pesta de 1489 i l'any posterior a València, Bernat Fenollar sembla ser que no es contagià i sobrevisqué a l'epidèmia. Ara per ara, la referència immediatament posterior al testament és del 24 de setembre de 1490. Aquell dia el seu germà Mateu, en nom propi i en el del mateix Bernat, nomena procurador al seu fill Tomàs perquè en el representació de tots dos gestionara uns assumptes relacionats amb l'herència dels seus pares, Joan i Iolant. ${ }^{63}$

El 14 de juliol morí Margarida, a la que en bona lògica degué assistir el mateix Bernat Fenollar. Unes setmanes més tard, el 28 d'aquell mes, documentem el domer «en lo studi de la casa del notari» Guillem Tovià per a assistir a la lectura pública del testament de la germana i acceptar «lo càrrec de la dita marmessoria per amor de nostre senyor Déu e per de la dita defuncta. E, axí mateix, dix que acceptava e de fet acceptà la dita herència ab benefici de inventari». ${ }^{64}$ Aquest inventari, però, no sembla que arriba a confegir-se mai. Durant gairebé un any perdem el rastre de Bernat fins que el 20 de setembre de 1491 realitzà diversos actes jurídics relacionats amb l'herència dels pares arran de la mort del seu germà uns dies abans. En concret, Bernat Fenollar «presbiter, minor dierum» com a fill i hereu de Mateu, hauria de satisfer a Bernat Fenollar «presbiter, maior dierum, domerius Sedis Valentie» el pagament del 2.811 sous i 8 diners corresponents a la dot de la seua mare. ${ }^{65}$

$\mathrm{Al}$ seu temps, Bernat Fenollar «presbiter, maiorque dierum, alterque exdomeriis Sedis Valentie, pro solvendis et paccandis» 4.000 sous al seu nebot Joan Fenollar «quos vobis solvere et dare promisi tempore vestri matrimoni» en 1484 li feia donació de diversos censals per valor de la dita suma. ${ }^{66} \mathrm{~A}$ més, com a hereu universal de la seua germana Margarida, lliurava a la seua neboda Fabiana un violari de 71 sous i 7 diners de pensió que d'aquella havia rebut. Unes setmanes més tard, Bernat nomenava procurador a Perot Fenollar, senyor de Benasau, llavors a Nàpols, «absentem vel ut presentem et cetera, videlicet, ad petendum, habendum et recuperandum omnes et singulas quantitates, res bona et cetera et pensiones censualium et violarium et alia quevis bona tam debitas quam decetero debendas, tam in dicta villa Penaguile quam in aliis partibus». ${ }^{67}$

Francesch Martí, huyt mília e huyt-cents sous per lo preu de dos censals que per aquell foren venuts al dit en Perot Fenollar ab CLXXXXVII sous VII de pro rata segons se mostra ab carta rebuda per lo discret en Guillem Thovià, notari, a XIIII de jener any propdit MCCCCLXXXXI». ARV, Protocols, no. 3.110.

63 APCCV, no. 25.159, protocols de Joan de Port.

64 ARV, Protocols, no. 4.244, protocols de Guillem Tovia.

65 APCCV, no. 26.399, protocols de Guillem Ramon Tovia (9-X-1491).

66 Idem. Com he apuntat a l'inici, resulta cridaner que només en aquest document figura Fenollar com 'exdomer' perquè en la resta d'actes enregistrats aquest dia és referit com a domer de la Seu.

67 Idem.

SCRIPTA, Revista internacional de literatura i cultura medieval i moderna, núm. 17 / juny 2021 / pp. 62-85 ISSN: 2340-4841 $\cdot$ doi:10.7203/SCRIPTA.17. 
A inicis de 1492, el domer liquidà els afers que havia gestionat com a procurador de l'esmentat Perot, que hauria mort en aquestes dates a Nàpols. ${ }^{68}$ Ho sabem perquè el 10 de febrer de 1492, a València estant, Lluís Fenollar, com a procurador de la vídua del seu germà Perot, «fent-vos gràcies de tanta cortesia e benefici» signava a Bernat un àpoca de 20.930 sous i 8 diners alhora que tancava la resta d'operacions que el domer havia realitzat en favor del difunt. ${ }^{69}$

De nou, les referències al domer comencen a ser escasses. Segons Martí Grajales, el 13 de gener de 1497 fundà un benefici a l'església de Sant Llorenç sota l'advocació de la Mare de Déu de la Salut (Martí Grajales 1894: 24). I tres anys després, el 15 de juliol de 1500 vinculava el patronat del benefici a la família dels Fenollar, instituint com a patrons els seus nebots, el notari Joan Fenollar i, a la seua mort, Tomàs. Tot i que els documents que esmenta Martí Grajales no ens han arribat, tot sembla indicar que el primer beneficiat fou un altre membre de la parentela, Joan Jeroni Fenollar ja que figura com a titular d'un benefici en una àpoca signada per alguns dels capellans de l'esmentada església el 17 de març de $1498 .^{70}$

Alguns anys més tard continuava encara al capdavant del benefici. Ho sabem perquè el 15 de febrer 1503 Bernardus Fenollar, presbiter domeris Sedis Valentie, signava el quitament d'un censal de 100 sous de capital i 10 de pensió a uns musulmans del lloc de Finestrat. ${ }^{71}$ Aquest censal havia d'estar vinculat al benefici fundat ja que tot seguit el mateix Bernat, com titular del cens, i Joan Jeroni Fenollar, com a clergue beneficiat de l'esmentada fundació, nomenaven procuradors perquè signassen la cancel lació d'aquest censal en els protocols originals on s'havia enregistrat el crèdit.

D’una altra banda, cal assenyalar que des de 1502 trobem en aquesta església un prevere beneficiat homònim de Bernat Fenollar amb el benentès que en cap cas se l'esmenta com a 'domer de la Seu'. ${ }^{72}$ És per això que l'identifique amb el nebot del nostre biografiat, el mateix a qui havia llegat alguns llibres en el seu testament de 1489. En efecte, el 18 de juliol de 1502, el vicari de la parròquia, Jaume Aparici, juntament amb els presbiteri et beneficiati dicte ecclesie Sancti Laurenti Miquel Dauda,

68 Sabem que Perot Fenollar va testar a Nàpols l'11 de juliol de 1491 i encara nomenà procurador el seu germà Lluís el 28 de novembre d'aquell any. APCCV, no. 25.159, protocols de Joan de Port.

69 Ídem.

70 Joan Jeroni Fenollar és esmentat amb la resta de «beneficiati int dicte ecclesie» però sense que s'especifique quin és el seu benefici. APCCV, no. 13.873. Cal apuntar que en una data anterior, el 31 d'agost de 1492 documentem cert Joan Fenollar «clerico diocesis Valentinensis, ville Penaguile nadino Valentie residentibus» tot i que no podem discernir si es tracta de la mateixa persona. APCCV, no. 12.098. Pere Andreu.

71 Cal fer notar que és un lloc relativament proper a Penàguila seguint el Camí del Peix que comunica la costa -amb nuclis com Benidorm la Vila Joiosa o el mateix Finestrat- amb les muntanyes d'Alcoi i que es feia servir per al comerç de peix fresc de la costa a l'interior i de neu en el sentit contrari. No és casualitat, per tant, que el censal hagués estat venut al seu pare Joan Fenollar. APCCV, no. 13.879, protocols de Pere Andreu.

72 En canvi, en la transacció de la casa que té lloc el mateix any, el Bernat Fenollar esmentat sí que apareix referit com a «domerius Sedis Valentie». ACV, Pergamins, no. 7.167.

SCRIPTA, Revista internacional de literatura i cultura medieval i moderna, núm. 17 / juny 2021 / pp. 62-85 
Joan Jeroni Fenollar, Bernat Fenollar, Joan Eslava i Nicolau Foix signaven una àpoca per el lluïsme d'una transacció sobre un immoble del que eren titulars. ${ }^{73}$ Tres anys després, el 1505 el notari Joan Fenollar, fill de Mateu, redactava el seu testament nomenant com a marmessor a Bernat Fenollar, «germà meu, beneficiat en la parròquia de sent Lorenç». ${ }^{74}$

Que aquest Bernat Fenollar, beneficiat de Sant Llorenç, no es correspon amb el domer ho apunta també el mateix notari que registrà aquesta documents, Pere Andreu. I això perquè si en les referències abans esmentades, el Fenollar referit apareixia com a beneficiat de Sant Llorenç, en els documents registrats el 1503, Pere Andreu sí que es referirà a ell com a 'domer de la Seu'. Així, doncs, el primer dels documents és el ja esmentat del 15 de febrer 1503 en el que Fenollar cancel lava el censal dels musulmans de Finestrat. ${ }^{75}$ L'altre document es registrà gairebé un mes després, el 18 març de 1503. Aquell dia, Dalfina Roís de Corella -germana de l'escriptor Joan Roís de Corella (Chiner 2013)- per tal de satisfer certes quantitats de diners al seu fill Enric Joan de Figuerola, acordava l'amortització del censal del què disposava el benefici amb «venerabili Bernardo Fenollar, presbitero, domerio Sedis dicte civitatis Valentie, institutore benefici per vos fundati in ecclesia Sancti Laurentii sub invocatione virginis Marie de la Salut, et vobis, venerabili Ioannes Ieronimo Fenollar, presbitero, beneficiato dicti beneficiì. ${ }^{76}$

\section{Quan morí el domer Fenollar?}

El fet que Margarida Fenollar premorira el seu germà obligava Bernat a redactar un nou testament atès que en el lliurat el 1489 ella figurava com a hereva universal. Calia, per tant, un nou testament o en el seu defecte un codicil per nomenar un nou hereu. Ultra això, el fet que no es féu lectura pública de l'esmentat testament suggereix, en efecte, que hi hagué un de nou. Però quan morí el domer de la seu Bernat Fenollar?

Martí Grajales en les seues edicions dels textos del domer aportà diverses notícies referides a la seua mort que ara no són accessibles ja. Així, en la introducció que el 1894 féu del llibre Trobes en lahors de la Verge Maria apuntà que en el Liber rationalis eclaesiae Sancti Laurentii quae rexit marcus arnes in anno $M^{\circ}$ $D^{\circ}$ XXV III ${ }^{\circ}$ hi constava que el «divendres, a XXV de setembre, celebraren aniversari per la ànima de mossèn Bernat Fenollar, domer de la seu, y de tots sos parents» (1894: 25). L'erudit entenia que la referència situava la mort del domer un any abans, el 1527, data que -com ell mateix feia notarresulta del tot excessiva atès que de ser cert Fenollar superaria els 80 anys.

\footnotetext{
73 APCCV, no. 13.876, protocols de Pere Andreu.

74 Guillem Ramon Tovia, no. 26.408 (8-VI-1505).

75 Cf. nota 64.
}

76 APCCV, no. 13.879, protocols de Pere Andreu. 
Probablement per això, en l'edició d'un altre text de Fenollar, Lo Passi en cobles, ell mateix avançà la mort del domer gairebé una dècada, fins a 1516 (1912: V). I això perquè de nou als registres de l'arxiu parroquial de Sant Llorenç trobà una anotació segons la qual «a XXVIII de febrer perno. a mossèn Bernat Fenollar ab sis preueres y creu». Ultra això donava una altra dada, aquesta estreta de la secció de Misses de trentenari: ${ }^{77}$ «darrer dia de febrer nos donà Jeroni Fenollar per ànima de mossèn Bernat Fenollar, prevere e beneficiat en la present sglèsia [de sant Llorenç], trenta misses de requiem ab offerta y canelles».

Martí Grajales identificava aquest Bernat Fenollar, 'prevere e beneficiat' amb el 'domer de la Seu', de manera que aquest hauria mort el 28 de febrer de 1516 (1912: V). A més, apuntava com a nova dada que en 1510 el Consell de València l'havia designat com a titular de la càtedra de matemàtiques de l’Estudi General (1912: V).

Això no obstant, Martí de Riquer ja va fer notar que aquesta identificació entre el beneficiat de Sant Llorenç i el domer no era plausible per l'avançada edat que implicava per al darrer (1964: 321). Recentment, Antoni Ferrando ha suggerit que el traspàs del Fenollar domer s'hauria produït alguns anys abans (Ferrando 2011: 171). La documentació exhumada en aquest treball reafirma rotundament el seu plantejament. En aquest sentit, crec que queda demostrat que el poeta de Penàguila sempre hi apareix a la documentació referit com a 'domer de la Seu'. Per tant, qui va morir el 1516 no fou ell sinó el seu nebot homònim, el mateix al què havia llegat alguns llibres en el seu testament. De la mateixa manera, fou el seu nebot i no ell el titular de la càtedra de matemàtiques de l'Estudi General.

Això implica que la data correcta per a la mort de Fenollar siga la inicialment referida per Martí Grajales de 1527? Em fa la impressió que, com ja han dit especialistes d'història de la llengua, això implica atorgar a Fenollar una edat del tot excessiva, ja que implicaria convertir al domer de la Seu en nonagenari, per bé que és cert que alguns individus dels sectors acomodats -i Fenollar ho era- arribaren a la vuitantena d'anys, com el primer duc de Gandia, Alfons el Vell (Castillo 1999: 219). Fins i tot del dia de celebració de l'aniversari que esmenta el document, el 25 de setembre, no se'n deriva necessàriament que aquesta fóra la data de la seua mort. Així, doncs, el document exhumat per Martí Grajales no permet ser categòric al respecte de la mort del domer. Únicament ens informa que alguns anys després de la defunció encara pervivia el seu record.

Quan es produí el traspàs és una dada que, ara per ara, se'ns escapa però indubtablement Bernat Fenollar, domer de la Seu de València, morí després del 21 de juliol de 1504. I això perquè, en aquest dia, Fenollar signà el quitament del violari que anys enrere, en 1497 concretament, havia comprat al seu company en la catedral i amic, el també domer Joan Montesino. ${ }^{78}$

\footnotetext{
77 Es refereix al Trentenari de Sant Amador, un conjunt de trenta misses que solien encomanar-se en el moment de confegir els testaments que va ser suprimit pel Concili de Trento.
}

78 APCCC, no. 26.404, protocol de Guillem Ramon Tovia (16-VI-1497).

SCRIPTA, Revista internacional de literatura i cultura medieval i moderna, núm. 17 / juny 2021 / pp. 62-85 ISSN: $2340-4841 \cdot$ doi:10.7203/SCRIPTA.17. 
Tot i la mancança d'una data precisa, alguns elements suggereixen la possibilitat que Fenollar pogués haver mort en la primera meitat de 1505, encara que -ho avance ja- no són definitius. D'entrada val apuntar que Bernat Fenollar no figura entre la nòmina de beneficiats que Milagros Carcel Ortí va confegir en el seu estudi sobre aquest col lectiu de la Seu de València (1980). Ultra això, cal assenyalar que a les darreries del mes d'abril d'aquell any, el paraire Pere Fuster i diversos membres de la família -per mediació del notari Joan Fenollar- vengueren 30 sous anuals de violari a «venerabile et discreto Bernat Fenollar, minori dierum, presbitero, habitatori dicte civitatis, ac beneficiato in parrochia beati Laurenti, absenti». L'operació creditícia en si ací no ens interessa però no deuria passar desapercebut aquest 'minori dierum' que implica necessàriament l'existència d'un 'maiori dierum' i que en bona lògica és el domer de la catedral. ${ }^{79}$

Aquesta referència pren encara més importància quan uns mesos més tard el mateix Joan Fenollar redactà el seu testament i nomenà marmessor Bernat Fenollar, «germà meu, beneficiat en la parròquia de Sent Lorenç». Si ja no calia diferenciar-lo de cap homònim potser devia de ser perquè el Fenollar domer ja era finat, tot i que no podem ser concloents al respecte. El ben cert és que al llarg de tot el document no hi ha cap esment al nostre biografiat malgrat que el notari demanà ser sebollit en el mateix lloc que el seu oncle: «en lo fossaret de la Seu de València, en aquell vas e capella e seminteri en lo qual són stats espellits mon pare e mare, e fills meus e altres de la mia parentela». ${ }^{80}$

Uns mesos més tard fou Joan Montesino el que redactà el seu testament nomenant com a marmessors Bernat Esteve, domer, i Joan Bexís, sotsdiaca de la Seu. ${ }^{81}$ Com en el cas anterior, no hi ha cap referència al nostre biografiat, la qual cosa, sense ser inequívoca, pot respondre al fet que el domer havia mort ja aleshores. La qüestió, per tant, de quan va morir el poeta i domer de la Seu Bernat Fenollar queda oberta per bé que ara sabem que el seu decés es va produir després de juliol de 1504.

79 APCCC, no. 26.408, protocol de Guillem Ramon Tovia (28-IV-1505).

80 APCCC, no. 26.408, protocol de Guillem Ramon Tovia (8-VI-1505).

81 Montesino redactà el seu testament el 19 de setembre de 1505 nomenament com a marmessors Bernat Esteve, domer, i Joan Bexís, sotsdiaca de la Seu. Morí el mateix dia i al sendemà s'efectuà l'inventari dels seus béns. La subhasta tingué lloc el 24 de setembre de 1505. APCCC, no. 26.408, protocol de Guillem Ramon Tovia. Esmentat per Villanueva (2017: 20). 
Frederic Aparisi. Noves consideracions al voltant de Bernat Fenollar, domer de la Seu de València

\section{Bibliografia}

Aparisi, F. (2016) Del camp a la ciutat. Les elits rurals valencianes a la baixa edat mitjana, Tesi doctoral inèdita, Universitat de València.

_. (2020a) "«Perquè ls tinga e liga en memòria mia». El testament de Bernat Fenollar (1499)", Estudis Romànics, 42, pp. 245 - 250.

- (2020b) "Nuevas aportaciones sobre la vida del médico judeoconverso valenciano Lluís Alcanyís (ca. 1440-1506)", Farmacia, Medicina e Historia, 150, pp. 4 - 21.

Arrizabalaga, J. (ed.) Alcanyís, Lluís (2008) Regiment preservatiu e curatiu de la pestilència, Barcelona, Barcino.

Cárcel Ortí, M. (1980) La diócesis de Valencia y sus beneficiados (1505-1538), tesi doctoral inèdita, Universitat de València.

Castillo, J. (1999) Alfons el Vell, duc reial de Gandia, Gandia, CEIC Alfons el Vell.

Chiner Gimeno, J.J. (2013) Ausiàs March i Joan Roís de Corella: relacions familiars, consultat en línea http:// www.cervantesvirtual.com/obra/ausias-march-i-joan-rois-de-corella-relacions-familiars/

Cifuentes, Ll. (2006) La ciència en català a l'Edat Mitjana $i$ el Renaixement, Barcelona, Publicacions de la Universitat de Barcelona.

Cohn, S. (2012) "Renaissance attachment to things: material culture in last wills and testaments", The Economic History Review Vol. 65, No. 3, pp. 984-1004.

Colón, G. / Ferrando, A. (2011) Les regles d'esquivar vocables a revisió, València/Barcelona, IIFV/PAM.

Cruselles, J. Ma (1999) Els notaris de la ciutat de València. Activitat profesional i comportament social a la primera meitat del segle XV, Barcelona, Fundació Noguera.

Downes, Stephanie, Sally Holloway i Sarah Randles (eds) (2018), Feeling Things: Objects and Emotions through History, Oxford, Oxford University Press.

Ferragud, C. (2018) "Despejando las sospechas: informes médicos en los tribunales de justicia de la comarca de la Ribera del Júcar (ss. XVI y XVII)", Dynamis: Acta hispanica ad medicinae scientiarumque historiam illustrandam, no. 38, pp. 65-86.

Ferrando Francés, A (ed.) Alcanyís, Lluís (1999) Regiment preservatiu e curatiu de la pestilència, Valencia, Universitat de València-Ajuntament de València,

—_. (1978) Narcís Vimyoles i la sena obra, València, Publicacions de la Universitat de València.

—_. (1983) Els certàmens poètics valencians, València, Institució Alfons el Magnànim.

—_. (2002) “Sobre l'autoria de les Regles d'esquivar vocables, encara”, Els Marges, 70, pp. 67-98.

Ferrer Gimeno, M. R (1987-1988) “La biblioteca del canónigo Matíes Mercader (1489)”, Estudis castellonencs, $\mathrm{n}^{\circ}$ 4, pp. 441-470. 
Frederic Aparisi. Noves consideracions al voltant de Bernat Fenollar, domer de la Seu de València

Ferrer Gimeno, M. R (1993) La lectura en Valencia, (1416-1474). Una aproximación histórica, Tesis doctoral inédita, Valencia, Universitat de València.

. (2016) "La biblioteca del predicador Pere Dorchal (1419)", En La España Medieval, 39, pp. 277-297. https://doi.org/10.5209/rev ELEM.2016.v39.52341

Garcia Sempere, M. (2007) "La correspondència amorosa entre Isabel Suaris i Bernat Fenollar: algunes puntualitzacions", dins López, A. / Cuesta, M. (eds) Actas del XI Congreso Internacional de la Asociación Hispánica de Literatura Medieval, León, pp. 581-588.

González Luis, J. (2014) “Autenticidad y datación del epistolario de séneca y san Pablo”, Fortunatae, No 25, pp. 169-181.

Guia, J. (2003) "Dades documentals d'interès literari (València, segle XV)" dins Compagna, A. Et al. Atti del VII Convegno Internazionale dell'Associazione Italiana di Studi Catalani (Napoli, 2000), pp. 201-221.

Guinot, E. (1999) Els fundadors del regne de Valencia. Repoblament, antroponimia i llengua a la València medieval, València, Tres i Quatre.

Martí Grajales, F. (1927) Ensayo de un diccionario biográfico y bibliográfico de los poetas que florecieron en el reino de Valencia, Madrid, Tip. de la "Revista de Archivos, Bibliotecas y Museos".

- (ed.) (1894) Les trobes en lahors de la verge Maria, València, Librería de Pascual Aguilar.

—. (ed.) (1912) Lo Passi en cobles, València, Imp. Federico Domènech.

Martínez Vinat, J. (2018) Cofradias y oficiós. Entre la acción confraternal y la organización corporativa en la Valencia medieval (1238-1516), Tesi doctoral inèdita, Universitat de València, 2018.

Menant, F. i Jessene, J.P. (eds.) (2007) Les Élites rurales dans l'Europe médiévale et moderne. Actes des XXVIIes Journées Internationales d'Histoire de l'Abbaye de Flaran. Presses universitaires du Mirail, Toulouse.

Mira Jodar, A. (2005) Entre la renta y el impuesto. Fiscalidad, finanzas y crecimiento económico en las villas reales del sur valenciano (siglos XIV-XVI), Publicacions de la Universitat de València, València.

Munsuri, N. (2007) Perspectiva socio-económica del clero secular en la Valencia del siglo XV, tesis doctoral, Valencia, Universitat de València, 2007.

Narbona Vizcaíno, R. (2020) “El dominio de Valencia sobre el vizcondado de Chelva (1395-1408): sobre la libertad de la ciudad y la libertad del reino", Edad Media. Revista de Historia, no 21, pp. 229-255. DOI: https://doi.org/10.24197/em.21.2020.229-255

Parisi, I. (2003-2004) "L'ambasciatore Joan Escrivà de Romaní i Ram e il libro delle Cartas Reales. Nuove fonti per lo studio delle relazioni tra la monarchia di Spagna e il regno di Napoli alla fine del “400”, Boletín de la Real Academia de Buenas Letras de Barcelona, XLIX, pp. 189-224.

. (2006-2007) "La famiglia Escrivà parente dei Borgia: Àngel Escrivà, figlio del maestro razionale del regno di Valencia, compagno di studi di Cesare e Giovanni Borgia", Revista Borja. Revista de l'Institut internacional d'estudis borgians, no. 1, pp. 103-119. 
Frederic Aparisi. Noves consideracions al voltant de Bernat Fenollar, domer de la Seu de València

Riquer, M. de (1964) Història de la literatura Catalana, vol. IV, Barcelona.

Rodrigo, Mateu (2016) "La llibreria del canonge Guillem Serra i el seu llegat a la Catedral de València (1489)”, Butlletí de la RABLB, LIV (2013-2014), pp. 137-204.

Rubio Vela, A. (1944-1995) "Las epidèmies de peste en la Ciudad de Valencia durante el siglo XV: nuevas aportaciones”, Estudis Castellonencs, 6, pp. 1.179-1.222.

Sanchis Sivera, J. (1999), Estudis d'història cultural, edició a cura de Francesc Pérez Moragon \& Mateu Rodrigo Lizondo, València/Barcelona, IIFV/PAM.

Valldecabres, R. (2002) El cens de 1510. Relació dels focs valencians ordenada per les corts de Montsó, València, Publicacions de la Universitat de València.

Ventura, J., Inquisició espanyola i cultura renaixentista al País Valencià, València, Tres i Quatre, 1978.

Vicens Vices, J. (2006) Historia crítica de la vida y reinado de Fernando II de Aragón, Zaragoza, IFC, ed. Miquel A. Marín Gelabert, or. 1962.

Vidal Beltran, E. (1974), Valencia en la época de Juan I, Publicacions de la Universitat de València, València, 1974.

Villanueva Serrano, F.(2017) "Una perspectiva prosopogràfica dels oficis musicals de la catedral de València en temps de Guillem de Podio, 1480-1505”, Anuario musical, 72, pp. 9-50. 